nourished in an unusual way, a way, however, that was indicated by V. Schytt in Geografiska Annaler, Årg. 31, 1949, p. 222-27.

Other work on the Baffin Expedition confirms the above conclusion. From the mountain belt to the east no true firn was observed at heights of ${ }_{5} 500 \mathrm{~m}$. At $1450 \mathrm{~m}$. near the summit of a peak near Eglinton Fiord a "snow" slope on the night $23 / 24$ July was composed of crystals of ice 5 to ro $\mathrm{mm}$. in size. The corrugations of the crystal boundaries held nailed climbing boots well despite the hardness of the slope which faced west. Yet the mountain glaciers in this region appear to be holding their own fairly well. The photographs in Figs. I3 and $I_{4}$ (p. I8), showing the glacier coming into the south side of Eglinton Fiord, were taken from exactly the same location on the opposite shore in 1934 and 1950. A slightly perceptible thinning in the lower section is visible, but no change in any way approaching that caused by the last sixteen years in, for example, Norway. A personal communication from P. A. Siple has confirmed the similar lack of firn near the summit of the ice cap in Devon Island.

It seems reasonable to deduce that many ice caps and areas of highland ice in Baffin, Bylot, Devon, and southern Ellesmere Islands are nourished in the way described and not by accumulation of firn snow, further that they may be at present in a rather healthier budgetary state than the majority of glaciers of the North Atlantic area. The conditions requisite for such "Baffin Type" glaciers would seem to be $(a)$ insufficient altitude to reach the local firn line, $(b)$ great residual cold in the ice, $(c)$ light precipitation, and $(d)$ the usual Arctic climatic environment of short cool summers and long cold winters.

It can be postulated also that most of these glaciers are survivals from before the post-glacial climatic optimum, since it is difficult to reconcile their reappearance since this time in the light of present-day low precipitation.

\title{
Part II: THE PHYSICS OF DEGLACIATION IN CENTRAL BAFFIN ISLAND*
}

\author{
By W. H. WARD
}

With an Appendix by Mason E. Hale

\begin{abstract}
Aвstract. The shearing and ablation of "cold" ice that leads to the formation of ablation and end moraines and the characteristic form of the S.E. edge of the Barnes ice cap are discussed. Some evidence suggests the existence of considerable areas of dead glacier ice extending well beyond the current moraines and completely insulated from melting by glacial debris. This debris consists of old moraines whose relief has been inverted and subdued. An appendix by Mason $\mathrm{E}$. Hale on the current moraine plant succession suggests that the last stable position of the S.E. edge of the ice cap occurred about 1860 and has been followed by retreat at an average rate of about $3 \mathrm{~m}$. per year.

RÉsumḱ. On a traite ici du cisaillement et de l'ablation de la glace "froide" d'où résultent la formation des moraines d'ablation et de termination, et la forme caractéristique du bord sud-est de la calotte de glace Barnes. L'évidence trouvée démontre l'existence d'une prolongation assez importante du glacier inerte au delà des moraines existantes. Cette partie du glacier inerte est recouverte par des dépôts glaciaires qui l'empêchent de foudre. Ces dépôts consistent en moraines anciennes dont le relief était renversé et moins accusé. La succession des plantes de moraine au bord de la calotte de glace fait l'objet d'une-annexe par Mason E. Hale. Cette étude montre qu'il est probable que le dernier état d'équilibre de la calotte se situe aux environs de i 860 et que depuis elle a reculé de $3 \mathrm{~m}$. par an en moyenne.
\end{abstract}

\section{INTRODUCTION}

In the previous paper, P. D. Baird has discussed the nourishment features of the Barnes Ice Cap and it is now of interest to consider the ablation zone, the modes of deglaciation and the

* A shortened version of this paper was read at a meeting of the International Commission on Snow and Ice, Brussels, August r95r. 
formation of glacial deposits in "Baffin type" glaciers and ice caps. As similar conditions may have existed in former times in other parts of north-east Canada and elsewhere, the following observations may be of interest in the interpretation of glacial deposits and frozen ground phenomena in these areas.

A map of the ice cap is given in Fig. 2 (p. 3) of Baird's paper. The area where most of the deglaciation studies were made by the writer lies at the southern end of the ice cap, near Generator Lake and camp A.2. A larger sketch map of this district is shown in Fig. I (p. 13) of this paper. Supplementary observations were made in the glaciated mountain region to the north-east and around Pond Inlet in northern Baffin Island.

\section{The Ice Temperature and the Absence of Melt Water beneath the Ice}

In the study of the deposition of glacial sediments one very important question is whether waterborne sediments can be laid down under the ice or not, or whether water erosion can occur beneath the ice. This depends on whether or not melt water issues from the base of the ice as it retreats and the glacier thins.

The firn temperature studies of Sverdrup, ${ }^{7}$ Hughes and Seligman ${ }^{2}$ and Sharp ${ }^{6}$ have shown that, where a thick layer of permeable firn overlies glacier ice, the latent heat evolved by refreezing of the infiltering summer melt water can be much greater than the heat lost by conduction during the winter. The temperature throughout the glacier ice under the firn is then that of the pressure melting point, although the mean atmospheric temperature may be below $0^{\circ} \mathrm{C}$. In such cases, there is a flow of melt water from beneath the ice, added to by surface melt water falling through transient crevasses kept open by circulation. Extensive deposition of glacial sediments on ground free of ice is possible, both beneath the ice and immediately in front of it. These are the more usual conditions assumed when interpreting glacial deposits, for example, the excellent study by Mannerfelt. ${ }^{3}$

Under "cold" ice the above possibility does not generally exist and glacial sediments can only be laid on top of the ice, except where the ice has flowed from the ground around nunataks and possibly in deep lakes and fjords where the mass of winter water may maintain the ground temperature at $0^{\circ} \mathrm{C}$. The concept of glacial retreat and thinning of the ice in the absence of bottom melting is perhaps strange, seeing that most experience has been confined to temperate glaciers.

On the Barnes Ice Cap, the small winter snow cover (less than I metre) and the impermeable glacier ice, prevent the summer melt water from rapidly cancelling out the great deficiency of heat in the ice resulting from winter temperatures. In the course of the summer innumerable melt water streams develop across the surface of the ice and dispose laterally of much of the summer heat. Hence in contrast to the temperate glacier, the steady ice temperature just below the zone of seasonal fluctuation could be even less than the mean atmospheric temperature.

It proved impossible to measure temperatures at great depth in the ice. It was colder than anticipated and the 300 metre thermal boring equipment was inadequately powered. Heat is required not only for warming and melting the ice, but also for maintaining the ice melting point. Nevertheless, several observations, described below, indicate that the $0^{\circ} \mathrm{C}$. isothermal is in the ground below the bottom of the ice.

First, at $\mathrm{A}_{2} \mathrm{X}$, see Fig. I, the temperature recorded by a "Stantel" thermistor frozen in a small hole at a depth of $9.2 \mathrm{~m}$. below the ice surface remained constant at $-10.7^{\circ} \mathrm{C}$. from mid July until the end of August when winter had already set in.* The ice thickness at this point is not likely to be much greater than the vertical distance to the bottom of Generator Lake, i.e. $120 \mathrm{~m}$. If the temperature had been $0^{\circ} \mathrm{C}$. at the base of the ice, the average temperature gradient in the

\footnotetext{
* This temperature may be compared to the mean annual upper air temperature of $-12.4^{\circ} \mathrm{C}$. in 1949 at the 950 millibar level recorded by the Canadian Department of Transport at Clyde Post, $160 \mathrm{~km}$. to the north-east on the Baffin Bay coast.
} 
ice would have been about $I \mathrm{Im}$. per $\mathrm{I}^{\circ} \mathrm{C}$. This gradient is about twice as steep as the maximum recorded anywhere in the ground (about $20 \mathrm{~m}$. per $\mathrm{I}^{\circ} \mathrm{C}$.) and with which it is comparable owing to the similar conductivity of ice $(\rho=0.9 \mathrm{r})$ and the underlying gneiss.

Secondly, there was no direct evidence of water flowing from beneath the ice, either on the ice cap or on the mountain glaciers. In a few places surface melt water issued from shallow tunnels in the ice. These were either partly re-frozen crevasses or deeply cut melt water channels bridged with old snow drifts. The ice is warmer locally where it abuts on to a large deep lake or fjord, and at one point $600 \mathrm{~m}$. behind the ice cliff of Generator Lake soundings in a deep hole suggested that surface melt water descended to lake level. Even so, in a shallow part of the lake a delta was being formed over an underwater extension of the exposed glacier ice.

Thirdly, there was a notable lack of permanently open crevasses on the ice cap and the glaciers, except close behind ice cliffs bordering deep lakes and fjords. On the other hand there were large numbers of re-frozen crevasses. Several narrow open crevasses seen early in the ablation season were later found to be frozen solid. At another point on the ice cap, several kilometres from the edge, late in the season, streams of water poured into a parallel series of sharp-edged crevasses not more than $20 \mathrm{~cm}$. wide. These crevasses traversed a major broad ice valley that earlier had carried, for a brief period, a slush river about $5 \mathrm{~m}$. deep and $50 \mathrm{~m}$. wide between snow levees. Many narrow frozen crevasses of the same series were also present. It appeared therefore that the open crevasses were of recent origin and were still being filled with water. Many re-frozen crevasses were seen on the steep mountain glaciers.

These three observations indicate that the temperature at the base of the ice is generally below the pressure melting point and that no water issues from beneath the ice. There are possibly local exceptions in the vicinity of large masses of lake and fjord water, where in winter the ice cover is only about $2 \mathrm{~m}$., and around nunataks from which the ice has flowed. Gradual thinning of the exposed "cold" ice near the edge, at least to a thickness corresponding to the depth of seasonal temperature change, would cause the temperature at the base of the ice to decrease. At this stage the ice may have become protected with surface debris and remain as permanent dead ice.

\section{The Debris-Laden Ice}

The central area of the ice cap and most of the ablation zone is remarkably free of rock debris, despite the valleys and undulations that occur in places. Small amounts of organic matter occur frequently in the ablation zone, but only at one point on the side of an interior valley, were a few square metres of rock debris seen. All the rock debris is concentrated around the ice cap periphery below a fairly well defined level. Even here exposures suggest that the average debris content is not more than few per cent by volume of the ice. The section in Fig. 2 (p. 13) is typical of the edge of the ice cap, a steep outer edge, a hummocky platform or hollow, and a slope above.

The debris varies from rock flour to large angular rocks; it is scoured from the ground beneath the ice and is carried upwards to the surface by the shearing or overthrusting of the ice near the edge.* This action is restricted to the edge, because the greater ablation has caused the outer ice to become dead, which in turn causes inward compression and passive flow with shear plane ruptures in the ice above. $\uparrow$ The shearing is rather irregular in time and position, and the largest abrupt displacement seen during the summer was about $45 \mathrm{~cm}$. at one place where the exposed dip was about $35^{\circ}$ inwards (Fig. 3, p. I9). More often a series of closely spaced shear planes seem to move gradually. The debris is concentrated in the shear planes, irregularly in thickness over

\footnotetext{
* The term "edge" is used to refer to the visible boundary of the ice beyond which lie ablation moraines. In places it is only an apparent edge, for buried glacier ice may extend considerable distances beyond the edge.

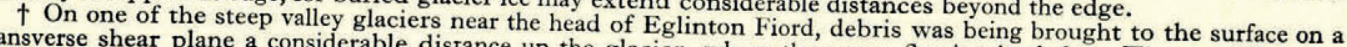
transverse shear plane a considerable distance up the glacier, where there was flowing ice below. The conditions are
different.
} 
their surfaces, and the spacing of the shear planes containing debris can vary from about a centimetre to many metres. The debris thickness is small and varies from a fraction of a centimetre to several centimetres. Large rocks are usually isolated, and elongated ones are generally orientated in the direction of shear. The dip of the exposed shear planes varies appreciably at different sections from a rare small outward dip to an inward dip of about $35^{\circ}$ maximum. Clearly, the slope (dip) of any one shear plane increases continuously in the direction of shear to a limiting value at the surface, and the dip of an inactive shear plane exposed at the surface depends on the amount of ablation that has occurred since shearing took place. The small outward dip of the shear planes was noted in the region of greatest recent retreat. The greatest shearing took place during the summer in the area of least retreat near section " $\mathrm{C}$ " (see Fig. I), in the zone rather above the dirty ice limit-a sign of current retreat rather than advance. The largest vertical section, about $20 \mathrm{~m}$. high, of shear planes containing debris was seen at the north end of Generator Lake ice cliff (Fig. 4, p. I9).

The debris in the ice is released in two ways, ( $\mathrm{I}$ ) by ablation, (2) by shearing of more active* ice over less active, or dead ice. Both processes take place at an active shear plane containing debris, but only the former process occurs at dead shear planes.

The subsequent distribution and motion of the released debris down the ice slope to form ablation moraine involves a number of complex processes which can only be studied by integrating observations at many different sections of the ice edge.

\section{The Melting-out of Debris entrained in the Ice}

The different rates of melting of glacier ice and snow in association with rock debris present a fascinating study in the exchange of heat between the surface and the atmosphere, and, in conjunction with the ice shearing, they form the basis of movement and construction of ablation moraines. The problem warrants an extensive physical study, but a few of the differences and dominant features may be summarized. They arise partly from the variations in the reflection of radiant heat. The reflectivity of the surfaces decreases in the following order, wet snow (0.6), clean wet ice $(0.4)$, rock debris $(0.4$ light to 0.1 dark). Further, the temperature of the melting snow or ice surface cannot rise above $0^{\circ} \mathrm{C}$., whereas the temperature of the rock debris surface is often much higher than the air temperature. On a sunny day both radiation and warm wind help to cause surface melting of snow and ice, while the radiation absorbed by the rock debris partly goes to warm the air. The screen air temperature over debris-covered ice was sometimes as much as $2^{\circ} \mathrm{C}$. higher than over the clean ice $70 \mathrm{~m}$. away. This condition was always accompanied by a strong outward breeze from the ice cap.

Ice containing rock debris or sprinkled with fine debris lodged amongst the surface crystals, but not generally covered with even a thin stable layer of debris, melts most rapidly. The radiation that penetrates the dirty ice is absorbed by the rock debris near the surface where it causes melting. Clean ice melts less slowly, appears more opaque, and the crystals near the surface are quite loose; the radiation penetrates rather deeper and there seems to be greater adsorption and melting at the crystal boundaries. Observations during the same period showed that, while the dirty ice melts more rapidly, temperatures recorded by two identical thermistors at a depth of $60 \mathrm{~cm}$. were between 0.5 and $\mathrm{I}^{\circ} \mathrm{C}$. lower in the dirty ice than in adjacent clean ice. These temperatures were taken to confirm earlier observations of the behaviour of identical birch dowel ablation stakes; those in the dirty ice, even in the bottom of streams, were always frozen firm in the ice, whilst those in the clean ice always melted loose towards the surface. Dirty ice covered with a continuous layer of stones or a few centimetres of sand or silt melts much more slowly; the melting rate

* The term "active" is not used in the Rankine sense as Nye 4 uses the word, but to distinguish moving ice from dead ice. 

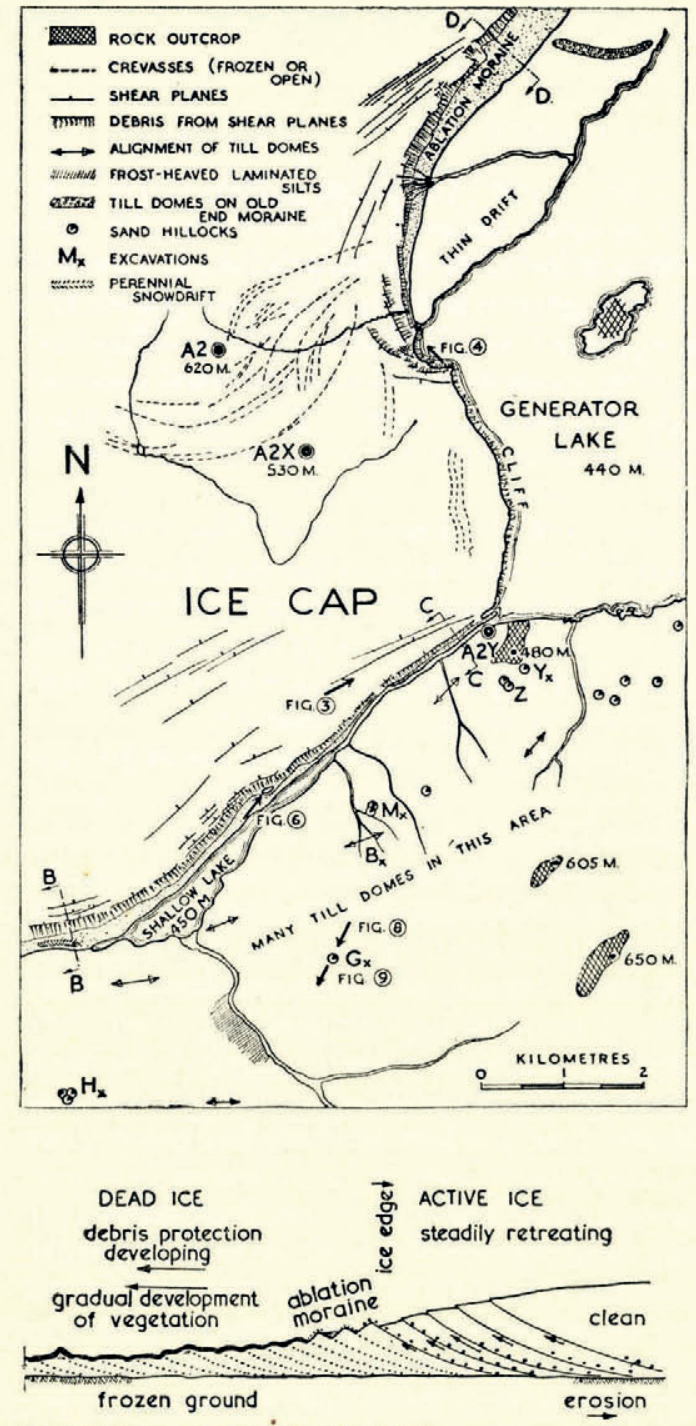

(a) STEADILY RETREATING ICE EDGE

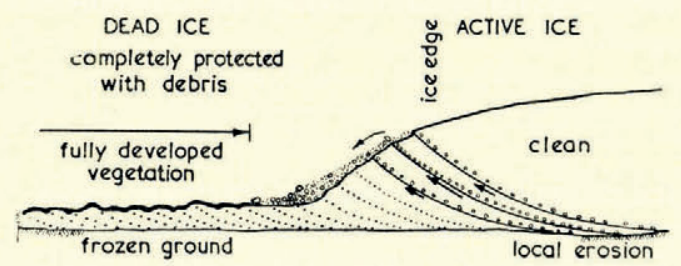

(b) STABLE ICE EDGE, FOLLOWING (a)

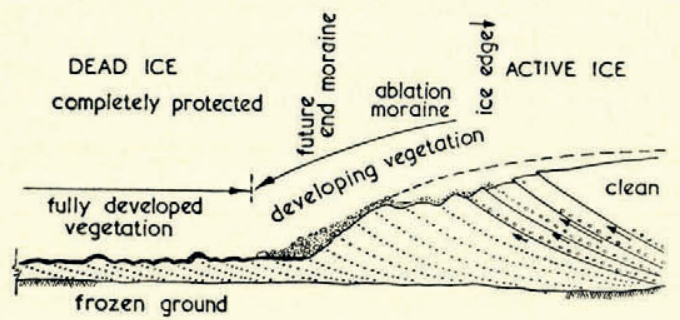

(c) RETREATING ICE EDGE. FOLLOWING (b)
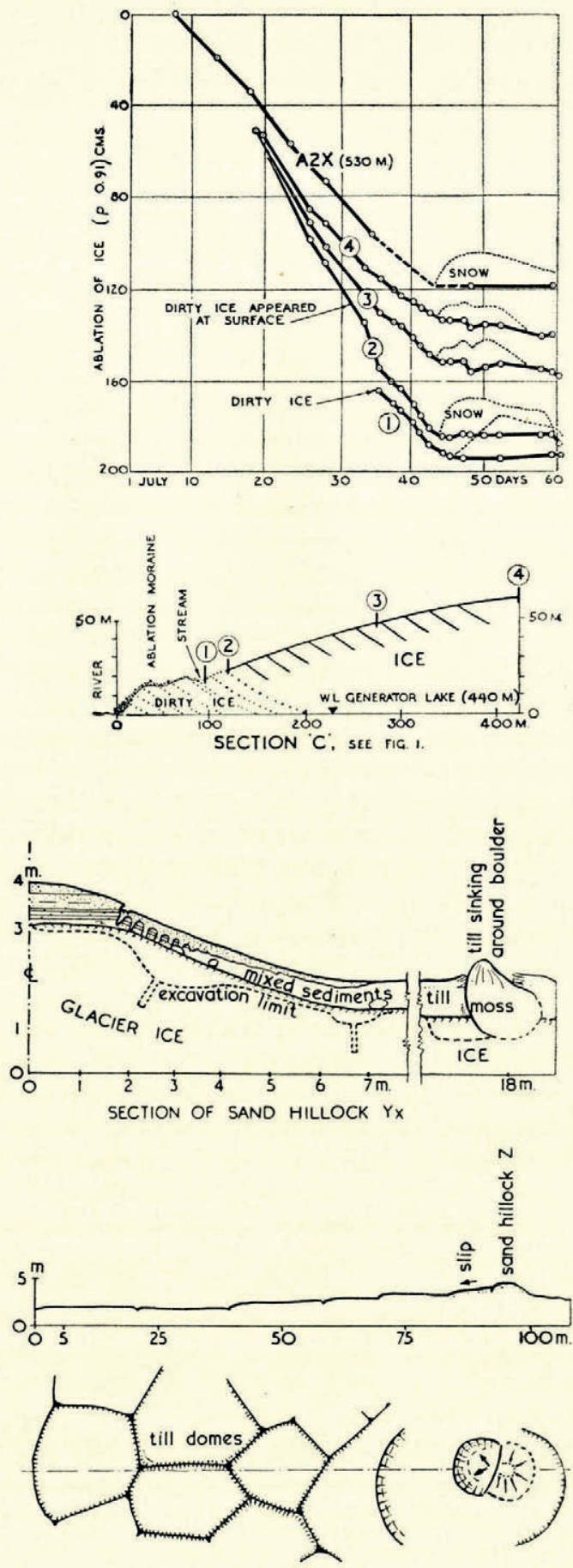

SECTION G PLAN OF TILL DOMES

Fig. I (top left). Map of south-east edge Barnes Ice Cap.

Fig. 2 (top two drawings right). Ablation rates and Section $C$

Fig. 7 (bottom three drawings left). Three forms of ice edge

Fig. Io (bottom three drawings right). Section of hilloc $Y x$; section and plan of hillock and dome $Z$ 
decreases rapidly with increase in the thickness of debris cover. The major portion of the heat that the debris absorbs from solar radiation is lost by radiation outwards when the sun is low and by conduction-convection to the air, before it can be conducted to the underlying ice. Drained quartz sand offers good protection on account of its higher reflectivity and better insulation compared to dark rock or wet clay till. A layer of coarse rocks is not so effective, because of internal air circulation. Fig. 2 shows the ablation of clean and dirty ice (not covered with debris) at different points on section "C" at the ice cap edge. The relative positions of some of the ablation-time curves are approximate only. The ice was clean when ablation stake 2 was first installed, but as melting ensued a band of dirty ice became exposed.

Isolated stones behave similarly. The small stones melt themselves in, slightly more into the clean ice than into the dirty ice. The same flat stone about $30 \mathrm{~cm}$. diameter and $15 \mathrm{~cm}$. thick, just large enough to form a small glacier table when originally resting on dirty ice, remained half buried on a clean ice surface and melted down with the surface for several weeks. Larger stones can form glacier tables on both clean and dirty ice. All but the largest stones were not elevated when the snow first cleared because they were "drowned" by the superimposed ice.

The effect of melt water streams on the rate of melting of the underlying ice is also important in deglaciation. During the period of stream flow the ice temperature decreases with depth, and it might be anticipated that melt water channels are limited in depth in view of the limited seasonal water supply and the considerable re-freezing of melt water that must take place early in the summer before the stream breaks out through the snow drift. Detailed observations on the deeper channels are difficult because their presence is not known until they break out, and later the water velocities are very high. Generally, their depth was quite limited and many abandoned stream courses were seen. Shallow streams near the ice surface, up to perhaps a metre deep, have very little effect on the rate of melting of the bed ice whether it is clean or dirty, provided the bank ice is clear of snow and surface debris. The channel depths remained approximately constant during the late summer even though more than a metre of ice was lost. Marked differences occur when the bank cover is different to the bed. It is noticeable in early summer and early winter when the banks are snow-covered and the streams run clear, and it is during these times that most deepening occurs in the clear ice areas. During early winter, after snow followed by slight thaws, ice accretion occurred on the banks, whilst melting proceeded in the bed. When stones roll down the sloping edge of the ice cap on to a shallow lateral stream above an ablation moraine, so that the stones project well above the water, they exhibit the same protective effect as if the stream were absent. Consequently the stream gradually moves away from the stones, that is to say, inwards towards the ice mass where the stone concentration is generally less and this tends to steepen the ice slope above.

The above observations were made on slopes generally facing southwards and differences would be expected at this latitude on slopes facing north.

\section{The Formation of Ablation Moraines}

Although the release of the debris in the ice and the subsequent movement of the debris varies appreciably in detail, a fairly regular pattern tends to develop from the geometry of the shear planes where the debris is initially concentrated. It is a pattern of line arrays that are (I) roughly parallel to the strike of the ice surface near the edge, (2) spaced downhill according to the positions of the shear planes containing debris and (3) spaced along the strike according to the original distribution of the debris within each shear plane. When the debris is released in sufficient concentration it forms rows of small cones and ridges of debris-covered ice irregularly spaced along and below the surface boundaries of the shear planes.

It is evident from observations on the ice cap and on glaciers near Eglinton Fiord that the shear 
planes develop progressively inwards away from the edge of a retreating glacier, provided that the underlying topography is fairly constant. Thus the zone of dirty ice gradually extends inwards, whilst the older dirty shear planes became inactive and release their dirt exclusively by ablation until the surface debris becomes protective. It must however take many decades for a new shear plane on the ice cap to begin to yield debris at its surface, and no shorter duration of retreat is likely to have a very significant effect on the exposure of superglacial debris. It will be seen later, however, that the effect of a stable edge or an advance is likely to be more striking.

The formation of ablation moraines at an active retreating ice edge, where the rate of downward ablation of clean ice is greater than the upthrust, can be considered by first studying the ablation of debris from an old static shear plane and then imposing a shearing motion.* Consider then the simple case of an uppermost static shear plane dipping into the ice and containing a good supply of rock. Higher up the ice slope than the shear plane there is no debris and lower down the slope is another shear plane where debris has already melted out. As the ice surface melts the debris from the uppermost shear plane slides and rolls down aided by the flow of melt water. Slowly the ice surface below the shear plane becomes covered with debris. The covering-up process varies with the debris and the slope. For example, when large boulders issue on to a slope, the familiar glacier tables are formed, the boulders topple over, roll some distance, stop and form another table and so on until they accumulate in profusion above a lower mass of melted-out debris. Till material or coarse sand produces a more rapid cover just below the shear plane.

When the ice becomes covered its rate of melting is reduced, the surface melt water from above is diverted and no longer disturbs the deposit. The ice surface above the shear plane therefore recedes and exposes the debris on the shear plane surface. This small ridge of debris-covered ice is the beginning of the growth of an ablation moraine. Fig. 5 (p. 19) shows a series of debris-covered ice ridges in various stages of development extending from a single shear plane on one of the mountain glaciers. It appears, although no measurements were possible, that this shear plane is only moving very slowly, if at all.

More often a series of closely spaced shear planes occur, each containing small amounts of debris that melt out together at the surface. The ridge formation is then not so abrupt in development and the rapid flow of slush and snow melt water in the early summer can easily spread the material downhill. An example of this is shown to the left and above the small lake in Fig. 6 (p. 20). The same remarks apply where relatively clean ice has receded appreciably and the shear plane dips away from the ice mass. Nevertheless a debris-covered ridge can develop in a similar way.

Although a thin debris cover reduces the rate of ice melting, it may be many years before sufficient cover is developed to prevent all further melting. A well developed ridge or cone, isolated from further surface additions of debris, will not persist unless there is adequate rock debris in the underlying ice to build up the cover by seasonal undermelting. Moreover, till debris containing a fair quantity of rock-flour is quite liable to slip off the underlying ice when the rate of thawing exceeds the rate of drainage. This exposes the apex but protects the base, and the more the apex is reduced the more the ridge is subdued and generally protected.

The ablation moraines have a marked effect on the shedding of melt water from the ice cap. The melt water is obliged to run parallel with the ridges, sometimes for long distances, but it breaks through occasionally where the original debris is scarce, or where an older outer melt water channel coming from the higher ice persists during moraine formation. Sometimes the water is ponded up by the ridges to overflow a low ice-cored ridge (see the lake in Fig. 6). In these places the sediments are laid on the ice in summer, but sometimes slush flows during the thaw, bringing in till and rocks. Here the ice cover is not controlled by local undermelting for it can rapidly accumulate in sufficient thickness to prevent the thaw line reaching the underlying ice. Where an ice valley with a large catchment area comes down to the ice edge, the life of the moraines is

* The shearing is generally so slow in Baffin Island that this is the most natural approach of a summer observer. 
short, for they may be overwhelmed by devastating floods of slush that spread the debris chaotically, and the life of the dead ice may be short.

When shearing takes place at the ice edge the rate of release of debris at the ice surface increases. The debris is likely to become more concentrated and the ridge-like formation more pronounced, provided the ice is capable of entraining a steady supply of debris from the rocks below. When the ablation of the ice above a shear plane is greater than the upward movement of the ice, a debriscovered ridge develops as described previously, but as the yield of debris is greater, the ridge is likely to be more adequately covered. If this steady retreat continues the active ice recedes and leaves behind a succession of ridges or rows of cones of debris-covered ice corresponding to the predominant positions of shearing at each interval of time. A glacial retreat is never, of course, a continuous steady process, but rather one of a series of moves from one position approaching stability to another. The form of the ice edge considered to be typical of a steady retreat is shown in Fig. $7 a$ (p. 13). Since the dead ice is always "cold," it is likely to persist unless it is particularly free of debris or the initial covering is rather thin.

The ice edge becomes stable when the shearing equals the ablation of the ice above the shear plane. In this case the simple condition of the shearing motion being restricted to one shear plane (or to a narrow zone of multiple shear planes), as has been assumed merely for the purposes of easier discussion, is much nearer the truth. The debris is released only at one fixed point or zone and a concentrated heap of surface debris is piled up. It may become a future end moraine. The form of a stable ice edge following a period of steady retreat is indicated in Fig. $7 b$.

If a period of slow steady retreat follows the previous stable position, the form of the ice edge is as shown in Fig. $7 c$. This is the general form of the ice edge on that part of the ice cap and those mountain glaciers seen by the writer. This form is dependent on the outer steep slope, which represents the stable position, having a cover of debris sufficient to prevent seasonal undermelting and not being subsequently eroded by a river. The level or sometimes hollow area with smaller ridges and cones of debris is due to the retreat producing a smaller concentration of debris and greater undermelting of the ice. The steeper slope above is due to the shearing of the ice despite the greater ablation. Only in one place for a short distance had a lateral river undermined the debris on the steep outer slope. Here the level hummocky zone was absent, since the subsequent release of debris had been insufficient to keep place with the river erosion. This condition seemed to be exceptional.

The width of the hummocky level zone varied from section to section according to the rate of retreat. Mason E. Hale made a study of the moraine plant succession at several sections, which gave an approximate time scale to the retreat. A summary of this study is given in the Appendix. It suggests that the maximum average rate of retreat since the stable position of about 1860 , is about $3 \mathrm{~m}$. per year, a figure that compares favourably with the current recession of 2 to $3 \mathrm{~m}$. per year.

Reports from some other parts of the ice cap by Dr. R. P. Goldthwait ${ }^{1}$ do not indicate recession.

\section{The Disappearance of Ablation Moraines}

The striking ridges and cones of ablation moraine adjacent to the edge of the ice cap generally terminate rather suddenly. There is no gradual reduction in their size as would be expected from a steady recession and melting of the ice cores, and the relief of the drift beyond is relatively subdued. The recent moraine is frequently ${ }_{5} 5$ to $60 \mathrm{~m}$. above the outer drift and extends up to $600 \mathrm{~m}$. from the exposed ice edge.

In some areas around the ice cap supporting the mature climax plant cover, the drift formations beyond the current ablation moraines are characterized by occasional conspicuous cones, flat 
hillocks and short ridges of yellow sand (Fig. 8, p. 20) dominating larger areas composed of many adjacent flat domes of glacial till, having the appearance of slumped heaps (Fig. 9, p. 20). The consistency of the upper $30 \mathrm{~cm}$. of till soon after it clears of snow and before a dried crust forms is that of sloppy concrete. The flat domes are generally about $20 \mathrm{~m}$. across and $0.6 \mathrm{~m}$. high but sometimes they are smaller and in other parts of Baffin Island frequently much larger. They are bounded from each other by small valleys, often containing a concentration of boulders, and by tiny lakes, as is shown in plan and section in Fig. 10 (p. I3). River valleys of a size compatible with the spate of slush in early summer dissect the ground deeply at intervals, but during most of the summer a mere trickle of water flows over a flat boulder pavement bed. Seen from the air the till domes form a striking pattern readily described as polygonal ground, but to avoid confusion this term is not used. It is at first difficult to see any regularity in pattern, but in places the domes are grouped in a series of parallel bands which could reasonably have been parallel to the ice edge at some time in the past.

In view of the absence of bottom melt water from under many parts of the ice cap it was considered that these drift forms arose from differential melting of dead glacier ice underlying older ablation moraines. The evidence subsequently collected, while requiring more thorough exploration, supported this hypothesis.

Excavations were made at the points marked in Fig. I during late July and August and in each case dead glacier ice was reached below debris which was or had been frosted.* The depths at which glacier ice was reached varied from about 50 to $100 \mathrm{~cm}$. for sand and till respectively, but these are likely to be minimum thicknesses, since the sites were selected for ease of excavation, and at these points the glacier ice lies roughly at the maximum depth of the thaw line. It was quite easy to distinguish the frost ice from the glacier ice. The glacier ice crystals were generally larger $(3-10 \mathrm{~mm}$.), not elongated or orientated by growth in the direction of heat transfer like frost ice, and occasional debris bands were never found parallel to the heat potential surface. No limit was found to the glacier ice thickness, the greatest depth penetrated being only $\mathrm{r} \cdot 5 \mathrm{~m}$., but a preliminary interpretation of gravity traverses indicates that it may be very much thicker in places.

* R. P. Goldthwait ${ }^{1}$ did not find any buried glacier ice in this area, neither did the writer on the occasions earlier in the season when they worked together. At this time the debris cover was still partly frozen and contained layers of frost ice and the writer found the labour of excavation discouraging. A portable concrete breaker would be very useful in exploring frozen ground.

Captions for page IS (text pages 2-9)

Fig. 4 (top left). General view of Camp AI from the meteorological tower

Photograph by M. H. W. Ritchie

Fig. 5 (top right). The ice edge north of Generator Lake showing the sharp limit of dirt-filled ice, surface streams and vegetation growing close to the edge

Photograph by $\mathcal{F}$. D. C. Waller

Fig. 6 (centre right). The ice cliff Generator Lake. The cliff was $30 \mathrm{~m}$. high and the water $30 \mathrm{~m}$. deep giving the ice thickness of $60 \mathrm{~m}$. at this point

Photograph by M. H.W. Ritchie

Fig. 9 (centre left). A "slusher" or surface stream. Note the levees thrown up when it "slushed out"

Photograph by W. H. Ward

Fig. 13 (bottom left). The glacier entering the south side of Eglinton Fiord taken by P. D. Baird in I950 from the same spot as Fig. 14. A slight thinning is perceptible

Fig. I4 (bottom right). The same glacier photographed in 1934 by a member of the Wordie Expedition

2 


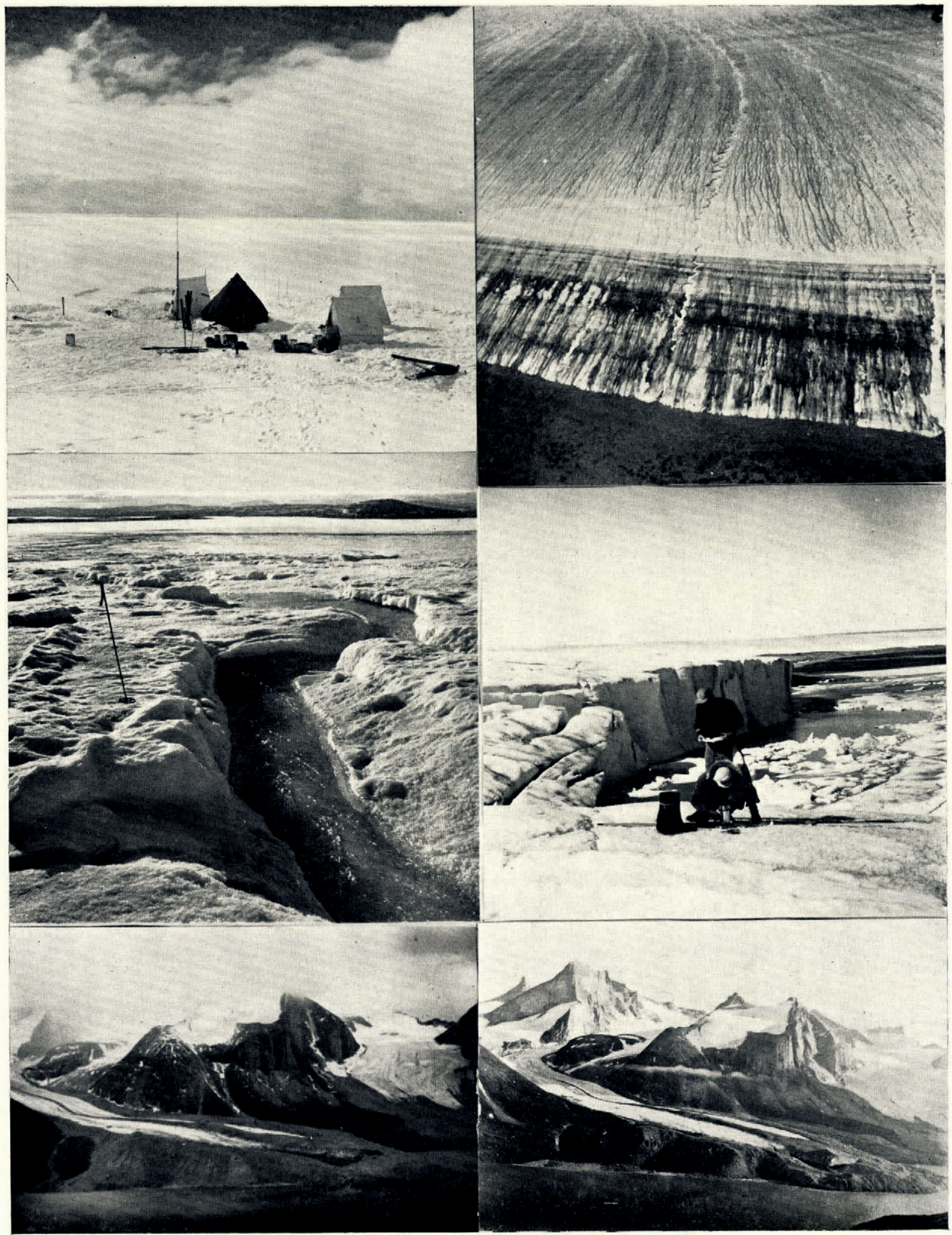

Captions at foot of previous page 


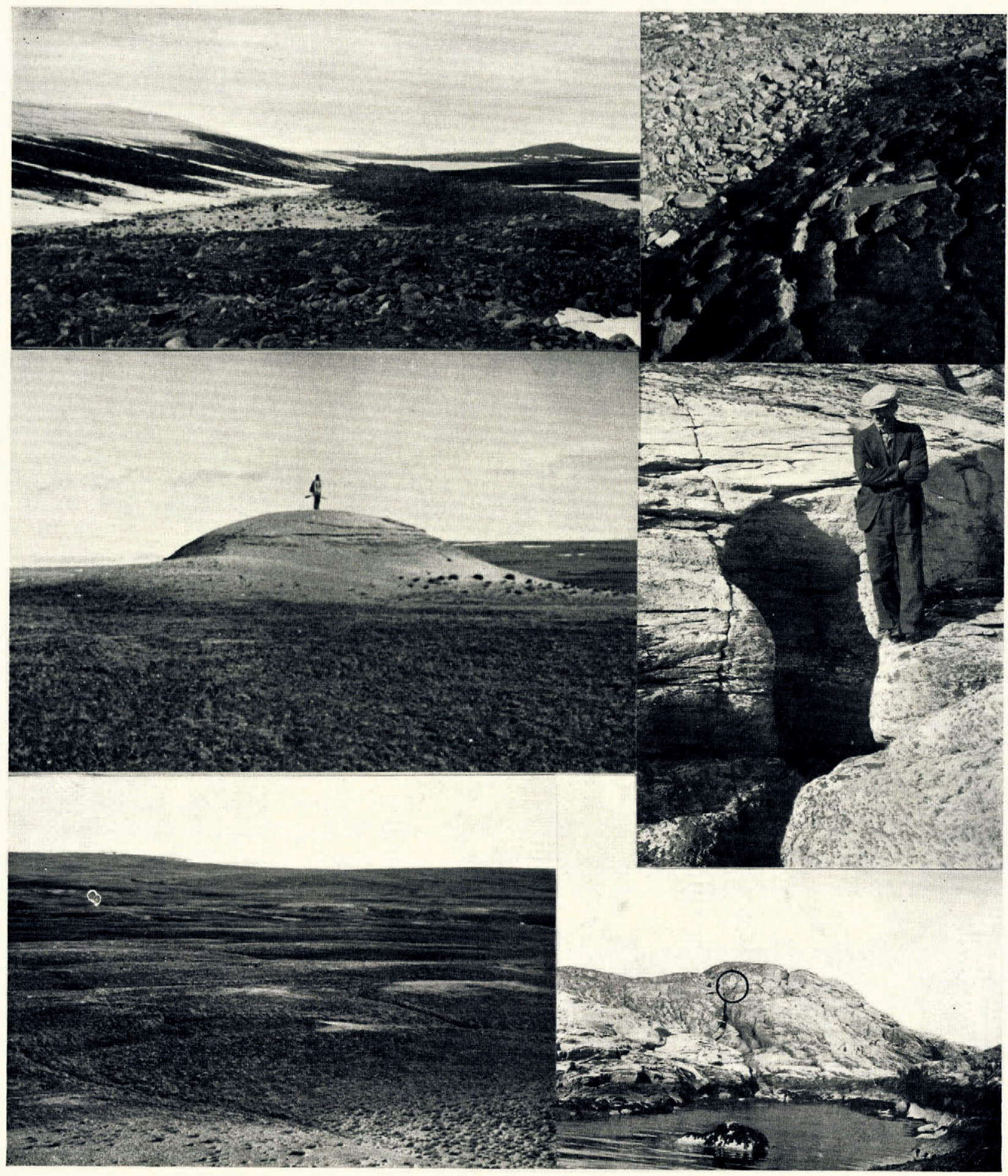

Fig. 6 (top left). Debris from a series of shear planes distributed down the ice edge. The small lake is depositing sediments on the ice (see text p. I5) Fig. 8. (centre left). Small hillock $G$ with an ice core covered with laminated silts and sands (see text $p .17$ )

Fig. 9 (bottom left). Flat domes of till adjacent to hillock $G$ (see text p. I7)

Fig. II (top right). "Alligator skin" on edge of flat dome of till. Dry boulder pavement of spring melt water stream beyond. Hand saw for scale (see text p. $2 I$ )

Photographs by W. H. Ward

Fig. I (centre right). Pot-hole in Kvannholmen, Norway (see text p. 25)

Fig. 2 (bottom right). Location of pot-holes in Kvannholmen. The water in the foreground is the head of a small bay cutting into the island from the west (cf. Fig. 3 in text p. 24) 
Excavations on several of the sand cones and hillocks revealed bedded sands overlying laminated silts followed in some cases by a thin layer of till. Odd boulders were also encounted. On top of the hillock the bedding was usually level and undisturbed, but all around the slopes the cohesive beds were torn apart and had flowed by small landslips about the central core of glacier ice. Sometimes recent slips formed tongues around the hillocks. A section through the sand hillock Y in Fig. I, is given in Fig. Io. Beyond the sand cone the mixed sediments thinned over typical till overlying glacier ice. The thinnest cover to the ice was usually found about halfway down the slope of the cone. Sand is occasionally blown off when it dries during the short summer, but this loss must be small. Similar sand cones and ridges covered with bedded sediments were seen forming amongst the current ablation moraines.

A typical plan and surface section of a group of till domes and an associated sand hillock is given in Fig. 10. The edges of the till domes frequently showed obvious signs of outward radial flow by (I) the "alligator skin" surface (Fig. I I, p. 20) adjoining the intersecting valleys where soil flow had taken place when a dried crust overlay very soft thawing till, and (2) the surface boulders congregating in and near the intersecting valleys where they had flowed more rapidly over the matrix of thawing till. The surface character of the domes and the flow of the material will depend upon the type of material present, in the same way that the behaviour of landslips depends on the type of ground involved. Most of the till encountered contained silt and rock flour and was subject to frost-heaving, and all the associated frost phenomena could be found on the surface of the domes. The water content of the surface till varied from about twice its liquid limit to below its plastic limit during the short summer, consequently a marked pattern of shrinkage cracks developed. Large boulders that rested in the underlying glacier ice and were visible above the surface remained stationary, while the frost-heaved till thawed and settled, giving a false impression of boulders being thrust out of the ground. In fact, during the critical period when the rate of release of thaw water exceeds the rate of drainage, a boulder about $60 \mathrm{~cm}$. in diameter would, theoretically, sink rapidly through the till, on account of the differential density and the low shear strength.

Thus both the sand hillocks and the till domes showed evidence of gravity slides and slips from local centres at higher levels, but clearly the sand hillocks, which are at present relatively high, must have been deposited in lakes and streams whose level was below the adjacent till domes in their original form. This is the inversion of relief, previously mentioned by many writers in studies of Alaskan temperate glaciers and recently discussed by Sharp, ${ }^{5}$ developed to a stable limit on "cold" ice.

It therefore seems reasonable to conclude that the sand hillocks originated in small lakes in the stream channels between the till-covered ablation moraines, and that, owing to the more adequate initial protection they provided to the underlying glacier ice, they melted down less slowly than the higher cones and ridges of the ablation moraine. The debris tends to slip from the ablation moraine soon after it develops. When this debris protection is still less than the maximum depth of the seasonal thaw line, additional layers of debris can be melted out from the dirty ice beneath the existing cover, and slipping of the debris is likely during the period when so much thaw water is released. The tongues of slipping debris radiate out from the local high points of the moraine until they meet opposing flows, to form the intersecting flat domes. Once the glacier ice is adequately covered with debris over a large area it is likely to persist indefinitely until the atmospheric heat is increased.

J. Davey Soper* found, in 1924-25 across the entrance to Pangnirtung Pass (South Baffin Island), a moraine about $45 \mathrm{~m}$. high underlain in many places by thick old ice, through which a river had since gnawed its way. This moraine was totally detached from any active glaciers of the locality, which had then receded far inland. 
When the zero isothermal rises to the base of the dead glacier ice, till will be slowly deposited in situ by bottom melting. So long as this till is below the zone of seasonal temperature change, it will be highly consolidated by the effective weight of the overlying ice. Seasonally the upper till will thaw out; owing to the release of frost water and to continual disruption, it is likely to be much softer than the lower till. Fresh debris will be slowly added to the lower surface of the upper till. "Cold" ice protected in this way is not likely to thaw out completely until the mean annual air temperature rises to about $0^{\circ} \mathrm{C}$. It might well exist to-day, together with relics of the patterns described above, in areas classified as permanently frozen ground.

The formation of thick glacial drift by slow melting in situ of protected debris-laden glacier ice is likely to be rather common where the ice has worked over soft rocks to produce a greater concentration of englacial debris than is present on the Barnes Ice Cap. The writer agrees with Sharp ${ }^{6}$ that areas of continental glaciation afford better opportunity than valley glaciation for preserving accumulations of superglacial origin, but would add that "cold" ice renders this possibility much greater.

\title{
ACKNOWLEDGEMENTS
}

The writer wishes to acknowledge helpful discussions with Dr. R. P. Goldthwait of the Ohio State University and the assistance of Mr. J. D. C. Waller of McGill University in the field. Acknowledgement is also made to the Royal Society for a grant and to the Department of Scientific and Industrial Research for facilities to enable the writer to carry out the work.

\section{R E F E R E N C E S}

I. Goldthwait, R. P. Development of end moraines in East-Central Baffin Island. Fourn. Geol. (in the press).

2. Hughes, T. P., and Seligman, G. The temperature, melt water movement and density increase in the névé of an alpine glacier. Monthly Notices; Roy. Astron. Soc. Geophys. Supplement, Vol. 4, No. 8, 1939, p. 6r6-34.

3. Mannerfelt, C. M:son. Några glacialmorfologiska formelement. Geogr. Annaler. Arg. 27, Ht. I-2, 1945, p. x-239.

4. Nye, J. F. The flow of glaciers and ice-sheets as a problem in plasticity. Proc. Roy. Soc. A, Vol. 207, p. 554-72.

5. Sharp, R. P. Studies of superglacial debris on valley glaciers. Am. Four. Sci., Vol. 247, 1949, p. 289-315.

5. Sharp, Thermal regimen of firn on upper Seward Glacier, Yukon Territory, Canada. Fourn. Glaciol., Vol. I, No. 9 , 1951, p. $476-487$.

7. Sverdrup, H. U. The temperature of the firn on Isachsen's Plateau, and general conclusions regarding the temperature of the glaciers on West-Spitsbergen. Georgr. Annaler, Ârg. 17, Ht. 1-2, 1935, p. 53-88.

\section{A P P E N D I X}

\section{MORAINE PLANT SUCCESSION AT THE EDGE OF THE ICE CAP}

\author{
By Mason E. Hale \\ (Department of Botany, University of Wisconsin)
}

Vegetation studies were made at four transects, three of which marked B, C and D are at positions shown in Fig. $\mathrm{I}$. The transects revealed the existence of rather definite zones, parallel to the ice edge, which were classifiable partly on morainic features and partly on the basis of plant communities. The morainic features may be due to cyclic recession of the ice. A diagrammatic profile containing all the zones found is given in Fig. 12 (p. 23). This was the situation at transect D and also in the area to the west of Fig. I.

Zone $\mathrm{r}$. Fresh moraine originating as the till is released from the ice, which often slumps to ower levels and thereby insulates the ice below very effectively, giving rise to a typically shaped moraine. Time of formation $\mathrm{I}-3$ years or an absolute date of $1947 \pm \mathrm{I}$ year. 